УДК 536.2

\title{
ЕКСПЕРИМЕНТАЛЬНІ ДОСЛІДЖЕННЯ ТЕПЛОПЕРЕДАЧІ ЧЕРЕЗ ЕНЕРГОЕФЕКТИВНІ СКЛОПАКЕТИ 3 НИЗЬКОЕМІСІЙНИМ м’яКИМ ПОКРИтТям
}

\author{
Басок Б.І., член-кореспондент НАН України, д.т.н., Давиденко Б.В., д.Т.н., Кужель Л.М., \\ Гончарук С.М., К.т.Н., Бєляєва Т.Г., К.Т.Н.
}

Інститут технічної теплофізики НАН Украӥни, вул. Желябова, 2а, Київ, 03057, Україна

Представлені результати досліджень теплотехнічних характеристик віконних склопакетів 3 низько-емісійним покриттям в реальних кліматичних умовах. Отримані експериментальні дані дозволяють визначити вплив різних факторів на теплові характеристики віконних конструкцій. Проаналізовані розподіл температур і густини теплового потоку на поверхні склопакету. Отримані експериментальні дані дають можливість визначити тепловтрати будівлі.
Представлены результаты исследования теплотехнических характеристик оконных стеклопакетов с низкоэмиссионым покрытием в реальных климатических условиях. Полученные экспериментальные данные позволяют определить влияние различных факторов на тепловые характеристики оконных конструкций. Проанализированы распределение температур и плотности теплового потока на поверхности стеклопакета. Полученные экспериментальные данные дают возможность определить теплопотери здания.
The results of studies of thermal characteristics of window-pane windows with low coverage in real climatic conditions. The experimental data allow us to determine the impact of various factors on the thermal performance of window designs. The distribution of temperatures ture and density of heat flow on the surface of the pane. The experimental data make possible to define the heat loss of the building.

Бібл. 9, рис.6.

Ключові слова: віконні конструкції, склопакети, експериментальні дані, теплові характеристики, тепловтрати будівлі, термомодернізація будівлі, і-покриття.

\section{Bcmyn}

Проблеми ефективного використання енергоресурсів і енергозаощадження в сучасних умовах є головним завданням забезпечення енергетичної безпеки, а тому відносяться до найважливіших стратегічних задач України. Одним з варіантів вирішення проблеми енергозбереження $€$ підвищення енергоефективності будівель та споруд, а саме: застосування комплексу заходів для покращення теплоізоляційних властивостей огороджувальних конструкцій будівель, а також проведення модернізації існуючих інженерних систем, що забезпечують необхідний тепловий комфорт. Питомі теплозахисні характеристики віконних конструкцій в декілька разів нижчі, ніж фасадних стін, що призводить до підвищених тепловтрат через вікна в зимовий період року і додаткових витрат на кондиціонування в літній період. У холодний період року через низьку температуру на внутрішній поверхні віконної конструкції істотно знижується комфортність приміщень. Крім того, світлопрозорі конструкції є малоінерційними в тепловому відношенні, а тому у них досить швидко змінюються теплові параметри внутрішніх поверхонь при зміні зовнішніх погодних умов. Тому актуальною є задача проведення комплексних досліджень теплопередачі через віконні конструкції з використанням склопакетів 3 низькоемісійним покриттям, особливо в реальних кліматичних умовах їх довготривалої експлуатації.

Аналіз останніх досліджень і публікацій, в яких започатковано вирішення даної проблеми. Найбільші тепловтрати зовнішньої оболонки будівлі відбуваються через віконні конструкції в зв'язку з низьким значенням ïx термічного опору теплопередачі, тому важливим завданням при підвищенні енергозбереження будівель різного призначення є оптимальний вибір саме віконних конструкцій [1]. Основними механізмами теплопереносу через такі конструкції $є$ : теплопровідність через скло, конвекція в газовому середовищі, що заповнює простір між склом, а також променеве теплоперенесення між внутрішніми поверхнями скла. Загалом зменшення теплопередачі через світлопрозорі огороджувальні конструкції досягається шляхом підвищення термічного опору скла і газового прошарку між склом, а також шляхом зниження рівня променевого теплопереносу [2]. Одним із способів підвищення опору теплопередачі світлопрозорих огороджувальних конструкцій, які впливають на променеву складову теплопередачі, $є$ застосування селективного покриття [3]. При виробництві скла 3 низькоемісійним м'яким покриттям як первинний матеріал використовують високоякісне листове скло [4]. Таке покриття нанесено шляхом напилення, що містить вільні електрони. Це покриття 3 напівпровідникових оксидів металів. За рахунок явищ інтерференції і електропровідності скло з таким покриттям відображає електромагнітні хвилі в інфрачервоному (тепловому) діапазоні, що дозволяє істотно скоротити тепловтрати. Параметром, що характеризує енергозберігаючі властивості скла, $€$ його випромінювальна здатність, під якою розуміють здатність поверхні відбивати довгохвильове теплове випромінювання. Для порівняння, такий параметр як емісситент поверхні (Е) у звичайного скла 
має значення $\mathrm{E}=0,835$, а у селективного $-0,05 \ldots 0.20$, що свідчить про те, що емісія селективного скла в декілька разів нижче емісії скла звичайного, звідки й інша назва енергозберігаючого скла - низькоемісійне скло (або Low-E). У холодний період низькоемісійне скло відбиває, наприклад, всередину приміщення теплоту від опалювальних приладів, а в літній час, навпаки енергозберігаюче покриття відбиває назовні теплову енергію в довгохвильовому діапазоні назовні, створюючи тим самим відчуття комфорту [5].

Постановка задачі. 3 метою обгрунтування заходів зі зменшення теплоспоживання (за умов дотримання належних санітарно-гігієнічних норм та створення належного рівня теплового комфорту) в існуючих будівлях, в Інституті технічної теплофізики НАН України проведено часткову термомодернізації адміністративної будівлі корпусу №1 по вул. Булаховського, 2 у м.Києві. Об'єктом досліджень при цьому стала теплоізоляційна спроможність віконних конструкцій досліджувальної будівлі, в якій була проведена заміна старих віконних конструкцій на сучасні енергоефективні 3

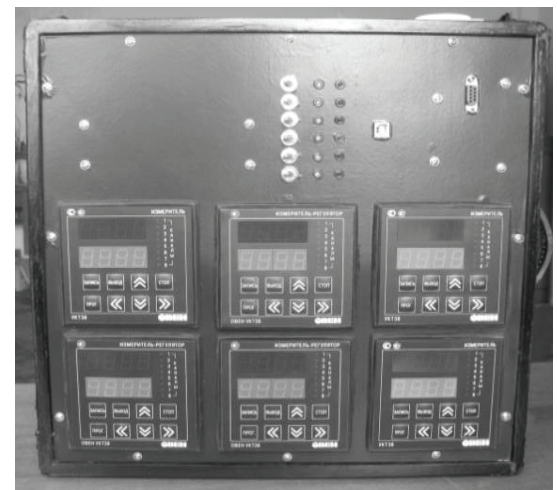

Рис. 1. Зовнішній вигляд блоку теплової реєстрації.

енергозберігаючими склопакетами [1]. Кількість різних варіантів конструкції енергозберігаючих вікон становила 20 шт. Встановлені вони були на строго північно орієнтованій стороні будівлі, куди не потрапляло пряме сонячне випромінювання.

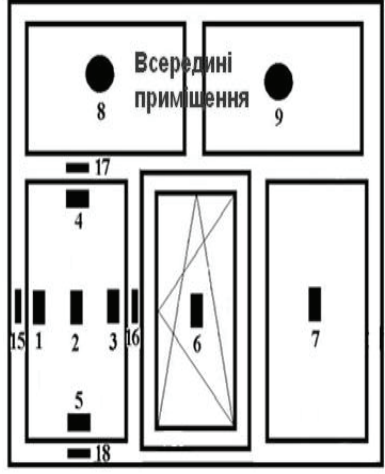

a)

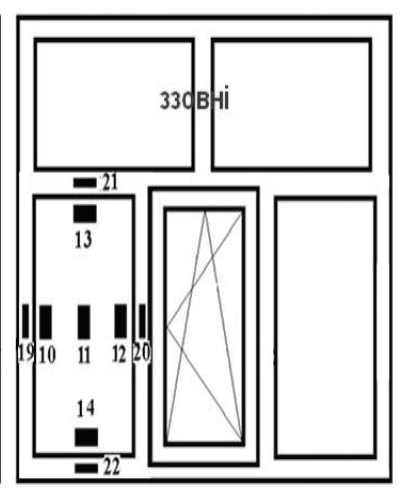

Pис. 2. Схема розмімиен

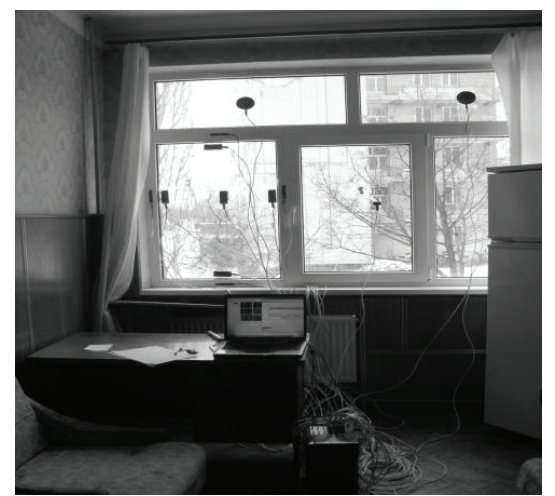

б) фотографія (б) досліджуваної віконної конструкції з розміщеними датчиками та підключеним вимірювальним комплексом (вигляд зсередини приміщення).

Віконні конструкції було встановлено у приміщеннях на другому поверсі північного фасаду триповерхової будівлі для того, щоб уникнути впливу прямої сонячної радіації на тепловий режим, а також для уникнення впливу даху (без горища) та підлоги першого поверху (без підвального приміщення). Для вимірювання температурних характеристик та тепловтрат через віконні конструкції було розроблено 96-ти канальний блок теплової реєстрації (БТР), який дозволяє в умовах реальної експлуатації будівлі досліджувати температурний стан будь-якої віконної конструкції [6]. Головним блоком БТР є комплектація шістьох восьмиканальних приладів вимірювання та контролю температури УКТ-38 для датчиків температури та шести восьмиканальних аналого-цифрових перетворювачів «Експерт» для датчиків теплових потоків. До цих приладів додавалась також відповідна кількість датчиків температури та теплового потоку зі з'єднананнями і адаптерами передачі даних. За допомогою спеціального кейса всі ці прилади об’єднані в одній вимірювальній установці, рис.1. В якості датчиків температури та теплового потоку було використано оригінальні датчики, в корпусі яких поєднувалися високочутливі датчики теплового потоку та платинові датчики температури типу Pt100. За своєю геометрією датчики 3 розмірами $40 \times 80$ мм були подібними до геометрії склопакету, а з розмірами $15 \times 80$ мм були подібними до геометрії віконного профілю, що було виконано відповідно до вимог [7]. Також для вимірювання тепловтрат через склопакети використовувалися датчики форми круга 3 діаметром 100 мм. Значення температури та теплового потоку фіксувались та записувалися через кожні 10 хвилин, тобто 144 значеня за добу. Схема розміщення датчиків та їх нумерація, показані на рис. 2. Похибка платинових датчиків температури становила $0,1{ }^{\circ} \mathrm{C}$, а мідних $-0,2 \ldots 0,3{ }^{\circ} \mathrm{C}$. Робочий діапазон зміни температури термометрів опору: $-40 \ldots+100{ }^{\circ} \mathrm{C}$. Згідно 3 [8] для проведення експерименту було обрано період, при якому температура зовнішнього повітря i температура всередині приміщення відрізнялися не менше, ніж на $15^{\circ} \mathrm{C}$. 
Однокамерний склопакет. Першочергово для експерименту було обрано приміщення, в якому встановлено однокамерний склопакет 3 низькоемісійним i-покриттям 3 формулою $6 \mathrm{M}_{1}-12$ - i6 (товщина скла 6 мм, відстань між склом 12 мм, на одне (внутрішнє) скло нанесене і-покриття). Графік залежностей температури та густини теплового потоку для такого склопакету представлено на рисунку $3 a, 3 \sigma, 3$ в.

Можна чітко відслідкувати, що експеримент був проведений при погодних умовах, що відповідають вимогам [8]. Провівши аналіз отриманих даних, можна зробити висновок, що значення температури датчика № 1, який розміщений всередині приміщення біля стінки, найнижчі через вплив холодної стіни. Значення на датчику № 4 - найвищі, а на датчику № 5 - найнижчі, що пояснюється опускною течією повітря поблизу склопа- кету та впливом стіни. Дані, що отримані з центрального датчику мають плавно виражений характер без різких підйомів і знижень теплового потоку та температури, на відміну від решти датчиків. Це дає змогу зробити висновок про те, що має місце відтік теплоти від центру склопакету до бокових поверхонь, а також є вплив того фактору, що профіль та склопакет виготовлені з різних матеріалів і мають різні теплофізичні властивості. Була проведена оцінка різниці температури між центральною точкою (№ 2) та точками, що розміщені збоку всередині приміщення. Різниця температур між точкою № 2 та точкою №1 (що знаходиться біля стінки) в середньому становила $0,5{ }^{\circ} \mathrm{C}$; різниця температур між точкою № 2 та точкою № $3-0,7^{\circ} \mathrm{C}$; між точками № 2 та № $4-0,3{ }^{\circ} \mathrm{C}$; а між точками № 2 та № $-1,15{ }^{\circ} \mathrm{C}$. На час проведення досліджень опалювальні конвектори були

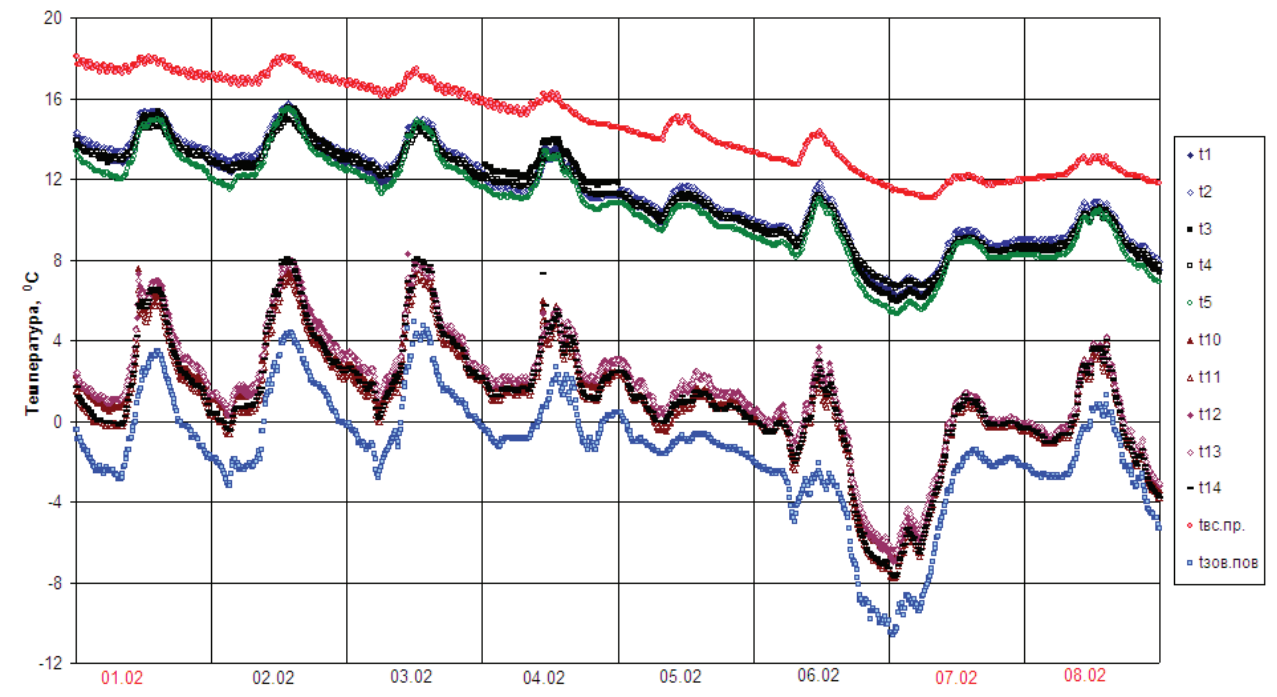

Рис. 3, а. Значення температури на внутрішній та зовнішній поверхні однокамерного склопакету 6М -12 - іб з і-покриттям, температури зовнішнього та внутрішнього повітря. Період вимірювання - 01.02.2015 з 00:00 до 08.02.2015 до 23:50.

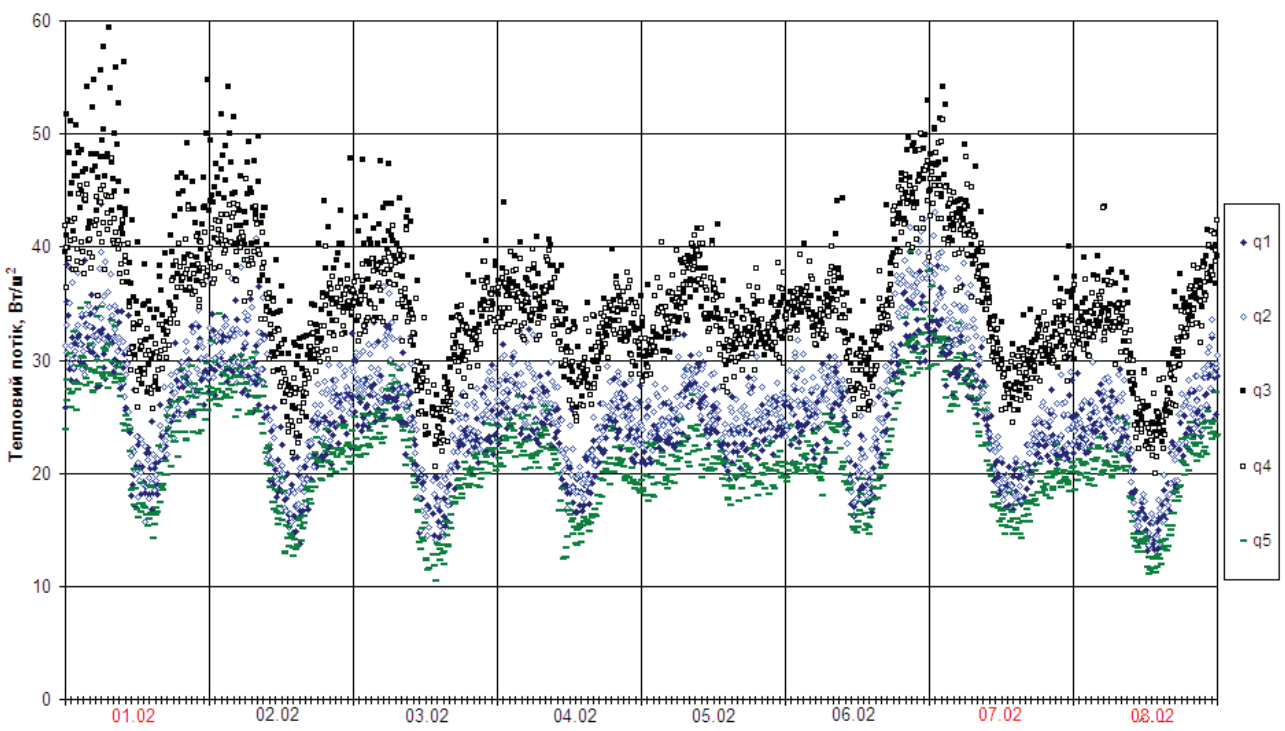

Рис. 3, б. Значення густини теплового потоку на внутрішній поверхні однокамерного склопакету 6М - 12 - іб з і-покриття.м. Період вимірювання - 01.02.2015 з 00:00 до 08.02.2015 - 23:50. 


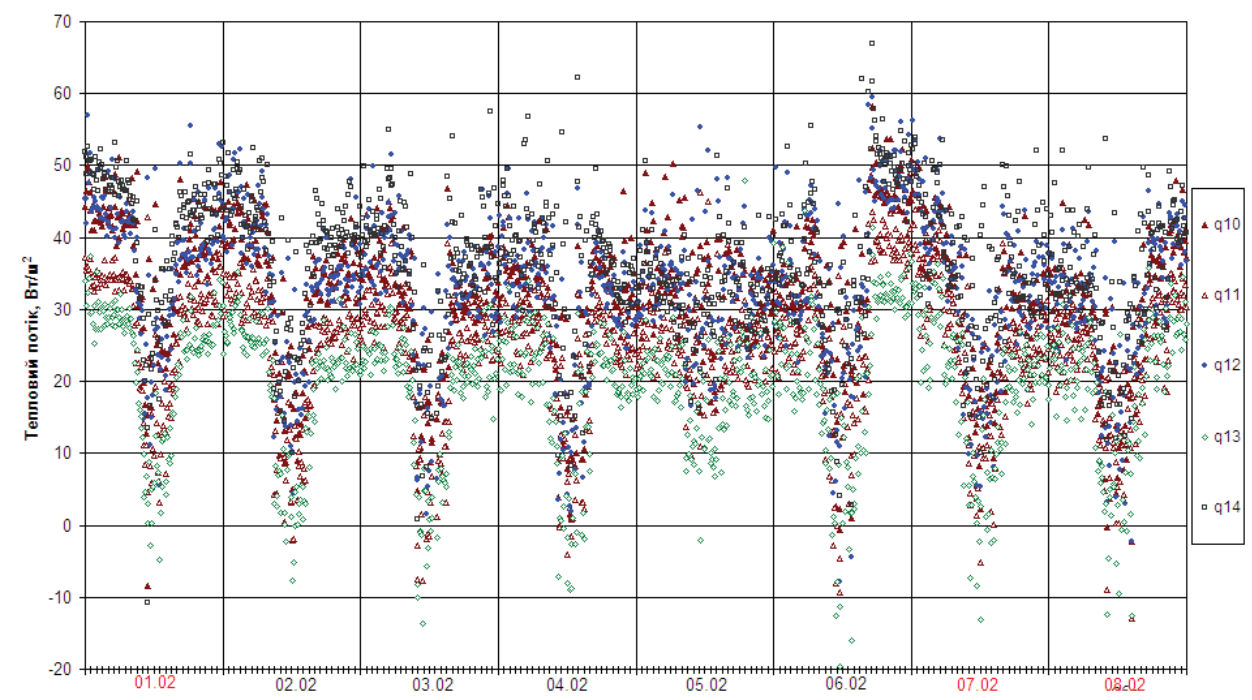

Рис. 3, в. Значення густини теплового потоку на зовнішній поверхні однокамерного склопакету 6М 1 - 12 - і6 з і-покриттям. Період вимірювання - 01.02.2015 з 00:00 до 08.02.2015 - 23:50.

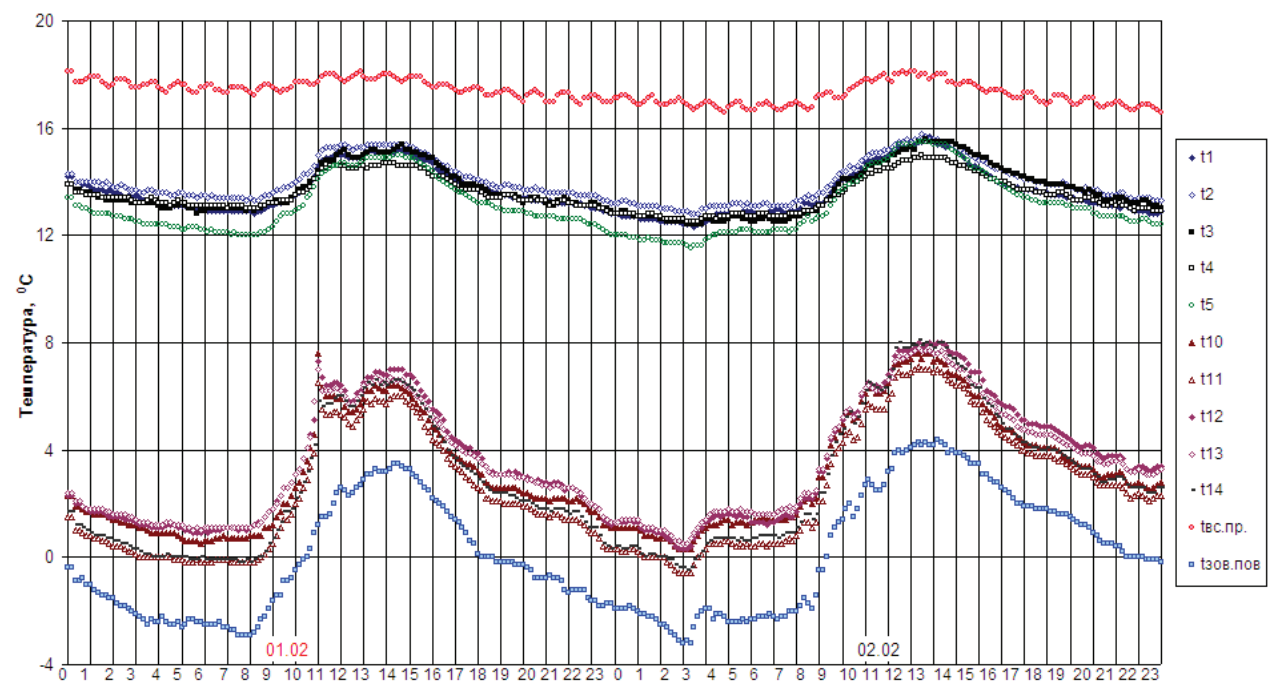

Рис. 3, г. Динаміка характерних температур склопакету 6М -12 - і6 в часі проведення досліджень, які були обрані для визначення термічного опору.

відключені у відповідності з вимогами [7]. Значення густини теплового потоку всередині приміщення та ззовні дещо відрізняється внаслідок впливу нестабільності зовнішніх умов та погодних факторів. В ті дні, коли були опади або пориви вітру, спостерігалися стрибки зовнішнього теплового потоку на рівні $20 \ldots 30 \mathrm{BT} / \mathrm{M}^{2} \mathrm{~K}$, а вплив розсіяної сонячної радіації чітко відслідковується в денні години.

В результаті обробки експериментальних даних було визначено термічний опір склопакета R, який $€$ характеристикою теплоізоляційної здатності огороджувальної конструкції будівлі. Чим більше його значення, тим менше теплоти проходить через віконну конструкцію. Для розрахунку термічного опору склопакета обиралися експериментальні дані, що одержані в нічні години (з 19:00 01.02. до 06:00 02.02.2015). В цей період відсутнє сонячне випромінювання та вплив людей в приміщенні. Процес теплопередачі в цей період можна вважати практично квазістаціонарним (рис. 3,2). Термічний опір досліджуваного склопакета становить -

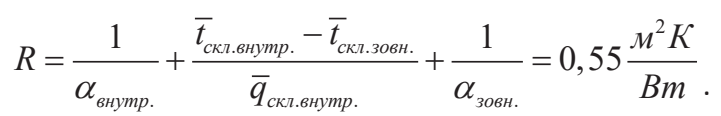

В діючому стандарті України [9] не приведено значення термічного опору саме для такого типу склопакету 
$6 \mathrm{M}_{1}-12-\mathrm{i} 6$. А отримане експериментальним шляхом значення $\mathrm{R}_{\text {о, експ. }}=0,55 \mathrm{~m}^{2} \mathrm{~K} / \mathrm{BT}$, показує, що однокамерний склопапкет з і-покриттям є достойним конкурентом двокамерному склопакету $4 \mathrm{M}_{1}-12-4 \mathrm{M}_{1}-12-4 \mathrm{M}_{1}$ без покриття, в якого значення $\mathrm{R}$ відповідно до [9] 0,49 м $^{2} \mathrm{~K} / \mathrm{B}$, а для близького за конструкцією однокамерного склопакету з низькоемісійним покриттям 3 товщиною скла 4 мм та відстанню між склом 12 мм, формула $4 \mathrm{M}_{1}$ - 12 - i4 значення термічного опору згідно [9] $\mathrm{R}=0,56 \mathrm{~m}^{2} \mathrm{~K} / \mathrm{BT}$.

Двокамерний склопакет. На наступному етапі досліджень визначалися характеристики теплопереносу через двокамерний склопакет з і-покриттям. Його формула - 4M-10-4M-10-4i (товщина скла 4 мм, відстань між склом 10 мм, на одне скло нанесене і-покриття).
Графіки залежностей температури та густини теплового потоку від часу наведено на рисунку $4, a, 4,6,4,6$. Можна побачити такі ж характерні зміни у показаннях датчиків, як і ті, що наведені на графіках для однокамерного склопакета. Тобто датчик, що розташований біля стіни, показує значення температури найнижчі, а в точці № 4, яка знаходиться у верхній частині склопакета, значення найвищі. За цими даними було визначено величину термічного опору двохкамерного склопакета, що враховує коефіцієнти тепловіддачі 3 поверхонь склопакета. Його величина, що визначалася у період часу, коли спостерігався квазістаціонарний режим (з 19:00 31.12.15 по 06:00 01.01.16), становить $\mathrm{R}_{\text {о, експ. }}=0,62 \mathrm{M}^{2} \mathrm{~K} / \mathrm{B}$. В стандарті [9] його значення становить $-\mathrm{R}=0,64 \mathrm{~m}^{2} \mathrm{~K} / \mathrm{B}$.

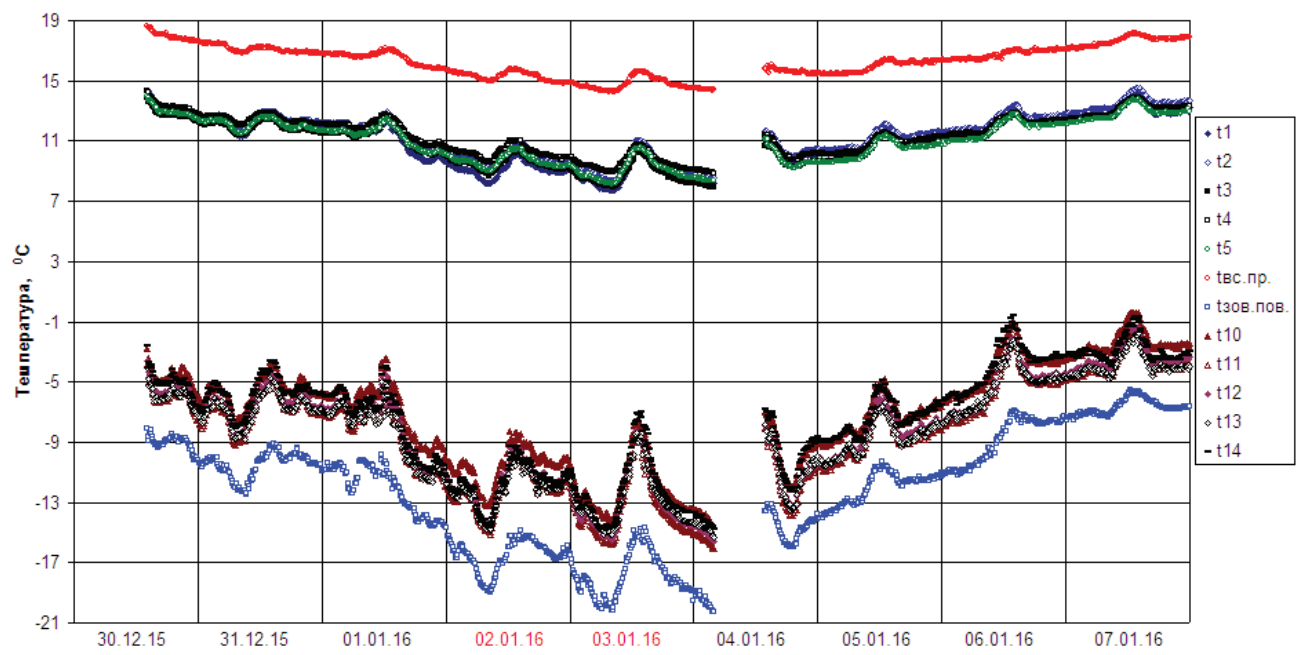

Рис. 4, а. Зміна у часі температури на внутрішній та зовнішній поверхні двокамерного склопакету 4M -10-4M -10-4і з і-покриттям та температури зовнішнього та внутрішнього повітря.

Електропостачання в будівлі було відсутнє 04.01 з 03:50 до 04.01 - 13:40.

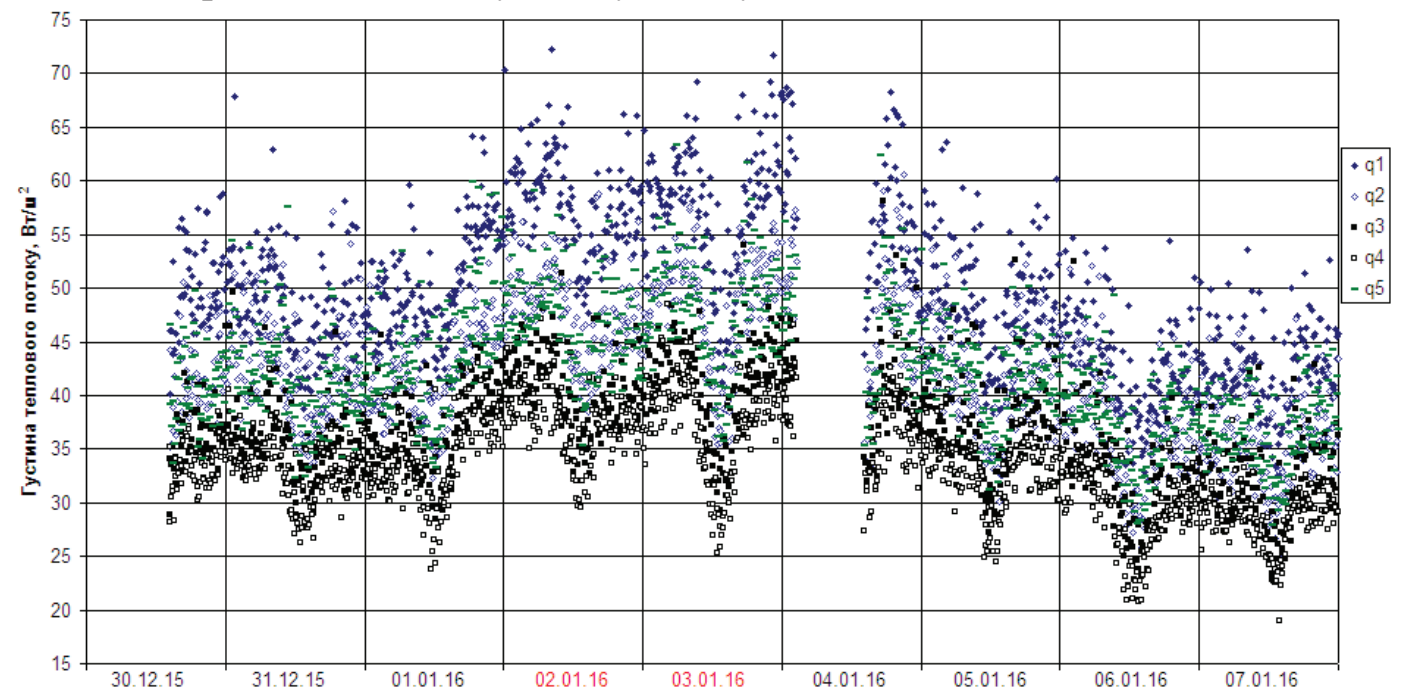

Рис. 4, б. Значення густин теплового потоку на внутрішній поверхні двокамерного склопакету 4M 1 -10-4M 1 -10-4і з і-покриттям. Період вимірювання-30.12.2015 з 14:00 до 07.01.2016 до 23:50. Електропостачання в будівлі було відсутнє 04.01 з 03:50 до 04.01 - 13:40. 


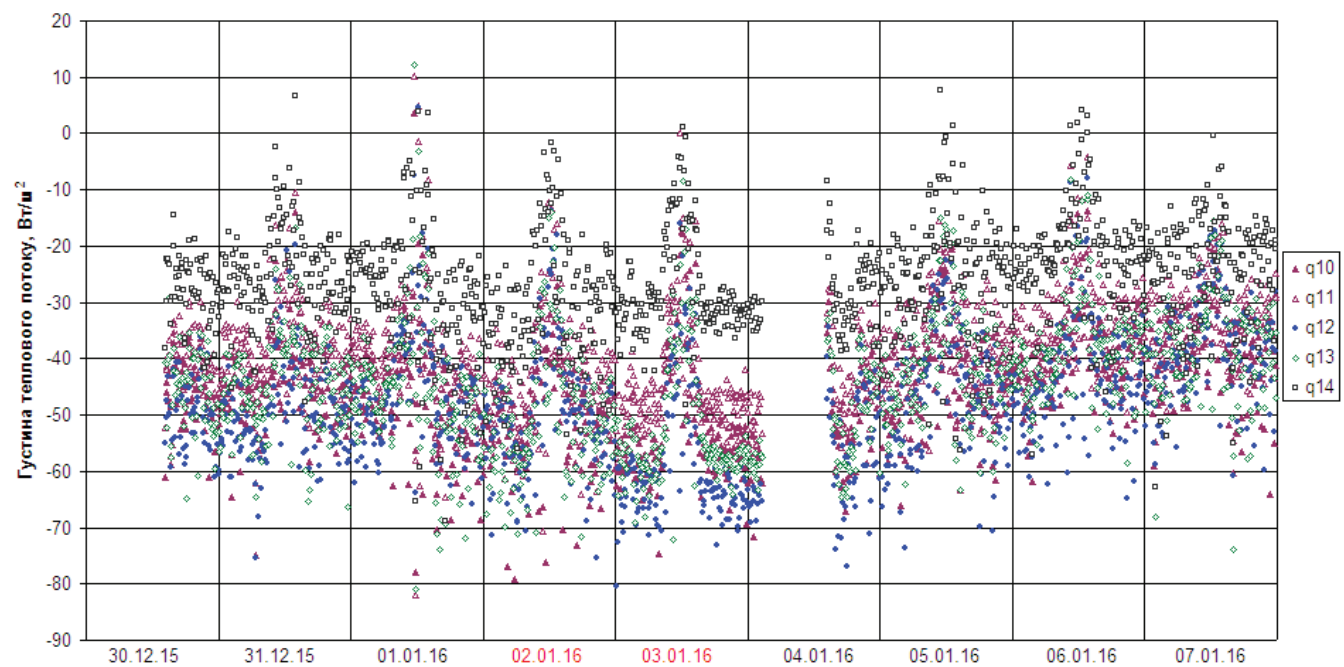

Рис. 4, в. Значення густин теплового потоку на зовнішній поверхні двокамерного склопакету 4 $M_{1}-10-4 M_{1}-10-4 i$ з i-покриття.м. Період вимірювання - 30.12.2015 з 14:00 до 07.01.2016 до 23:50.

Електропостачання в будівлі було відсутнє 04.01 з 03:50 до 04.01 - 13:40.

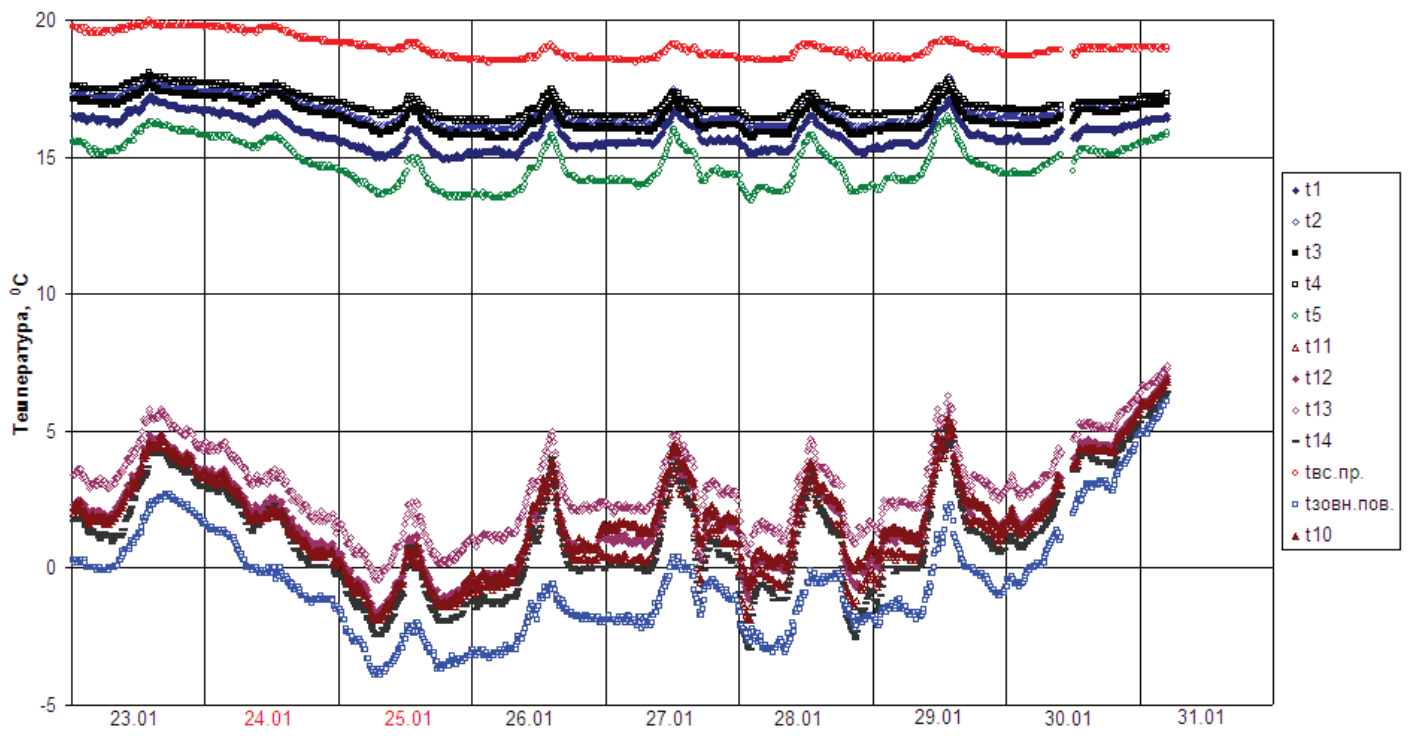

Рис. 5, а. Зміна у часі температури на внутрішній та зовнішній поверхнях двокамерного склопакету 4M -20-4M $_{1}$-20-i4 з i-покриттям та температури зовнішнього та внутрішнього повітря.

Період вимірювання - 23.01.2015 з 00:00 до 31.01.2015 - 04:50.

Електропостачання в будівлі було відсутнє 30.01 з 09:40 до 11:50.

Наступний етап експериментальних досліджень проводився 3 метою визначення характеристик двокамерного склопакетом 3 одним і-покриттям, який відрізнявся від попереднього більшою відстанню між склом: 20 мм. Його формула $-4 \mathrm{M}_{1}-20-4 \mathrm{M}_{1}-20-\mathrm{i} 4$. I3 збільшенням ширини дистанційної рамки і відстані між склом, теплоізоляційні характеристики підвищуються, а також покращується шумоізоляція. На рис. 5, a i 5, б приведені відповідні графічні залежності. В діючому стандарті України [9] для такого типу склопакету значення опору теплопередачі не приве- дено, а наведено значення опору для склопакета, формула якого 4M-16-4M-16-i4. Відстань між склом у цьому склопакеті становить 16 мм, а величина опору теплопередачі - 0,72 м²К/Вт. Для досліджуваного склопакета з формулою 4M-20-4M-20-i4 експериментально знайдена величина опору становить $\mathrm{R}_{\text {о. експ. }}=0,96 \mathrm{~m}^{2} \mathrm{~K} / \mathrm{BT}$, що на $20 \%$ перевищує нині діючі непо нормативи для світлопрозорих конструкцій. Отже, шляхом збільшення ширини камер склопакета, що заповнені повітрям 3 низькою теплопровідністю, досягається таке високе значення опору теплопередачі. 


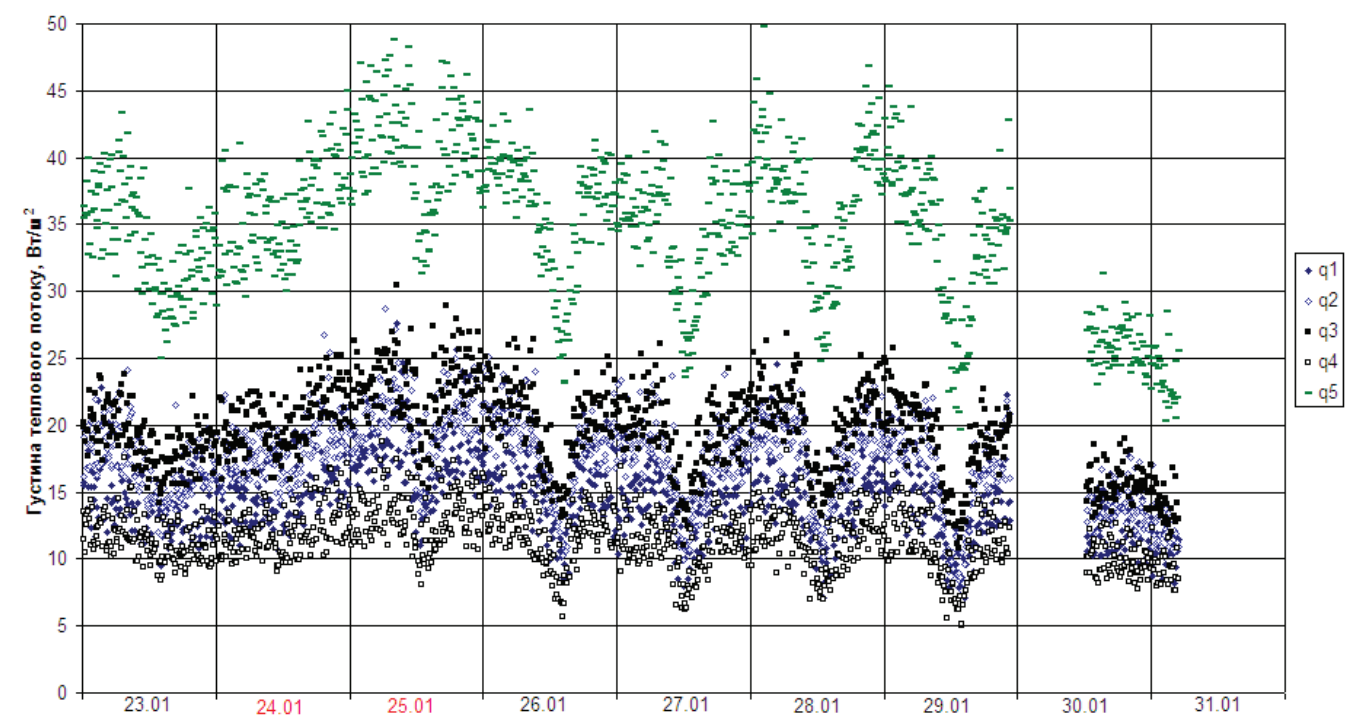

Рис. 5, б. Значення густин теплового потоку на внутрішній поверхні двокамерного склопакету 4M -20-4M-20-i4 з і-покриттям. Період вимірювання - 23.01.2015 з 00:00 до 31.01.2015 - 04:50. Електропостачання в будівлі було відсутне з 29.01 з 22:40 до 30.01 - 12:00.

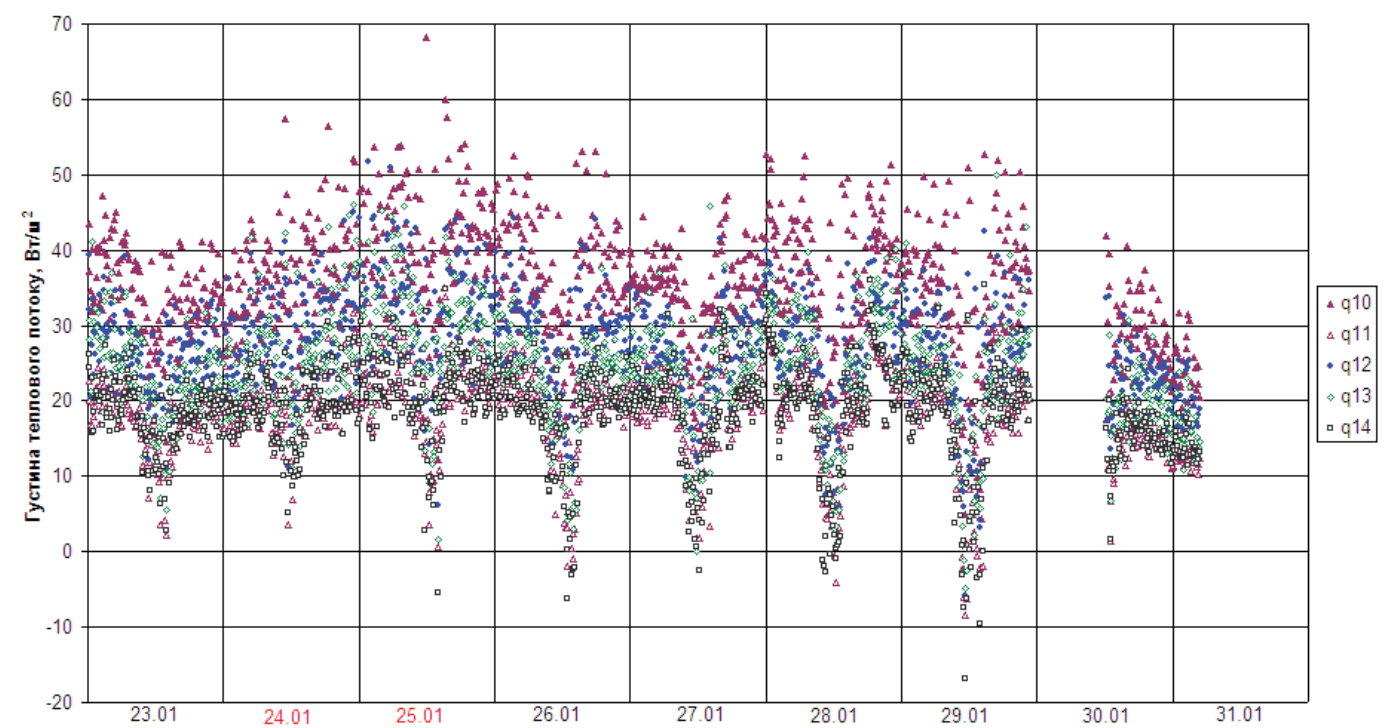

Рис. 5, в. Значення густин теплового потоку на зовнішній поверхні двокамерного склопакету 4M -20-4M-20-i4 з і-покриттям. Період вимірювання - 23.01.2015 з 00:00 до 31.01.2015 - 04:50. Електропостачання в будівлі було відсутне з 29.01 з 22:40 до 30.01-12:00.

\section{Висновки}

Провівши серію експериментальних досліджень та проаналізувавши всі отримані результати, можна зробити висновок, що оптимальним варіантом для заміни старих віконних конструкцій являються склопакети 3 низькоемісійним м'яким покриттям. Проведені дослідження показали, що за рахунок нанесеного покриття на поверхню скла зменшується радіаційна складова теплового потоку, що сприяє збільшенню значення термічного опору, а відповідно і зменшенню тепловтрат через світлопрозорі конструкції. При збільшенні відстані між склом в склопакеті до 20 мм опір теплопередачі збільшується. Тому можна рекомен-

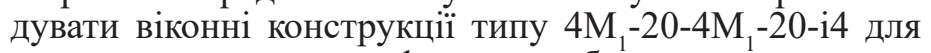
встановлення в енергоефективних будинках, наприклад в будинках пасивного типу.

\section{ЛІТЕРАТУРА}

1. Басок Б.І., Давиденко Б.В., Гончарук С.М., Кужель Л.М. Експериментальні дослідження теплопереносу через сучасні віконні конструкції в реальних умовах експлуатації [Електронний ресурс] / Басок Б.І., Давиденко Б.В., Гончарук С.М., Кужель Л.М. / Режим доступу: http://wt.com.ua/wt_60_2015_online/flippingbook.swf

2. Басок Б.И., Давиденкко Б.В., Новиикая М.П., Гончарук С.М., Недбайло А.Н. Влияние толщины газовой 
прослойки на термическое сопротивление однокамерного стеклопакета // Пром. теплотехника, 2012, т.34, №1, C. $100-107$.

3. Петров Е.В., Качаева С.Г., Алексеев А.А. Исследование влияния различных факторов на тепловые характеристики светопрозрачных ограждений // Научный вестник № 1 (1) 2014, С. 99 - 105.

4. Сучасні украӥнські будівельні матеріали, вироби та консттрукиї. Науково-практичний довідник /К: Асоціація "Всеукраїнський союз виробників будівельних матеріалів та виробів”, 2012.

5. Посильский О. Современные виды энергосберегающих стекол. [Електронний ресурс] / О. Посильский / Режим доступу: http://www.ivit.ua/article/sovremennye vidy_energosberegayushih_stekol

6. Давиденко Б.В., Гончарук С.М., Новіцьька М.П., Кужель Л.М., Красота Д.О. Експериментальні дослідження теплопереносу через сучасні віконні

\section{EXPERIMENTAL STUDIES OF HEAT ENERGY EFFICIENT GLASS UNITS WITH LOW SOFT SURFACE}

\section{Basok B.B., Davydenko B.V., Kuzhel L.M., Goncharuk S.M., Belyaeva T.G.}

Institute of Engineering Thermophysics of the National Academy of Sciences of Ukraine, 2a, Zhelyabova str., Kyiv, 03680, Ukraine

Key words: window construction, windows, experimental data, thermal performance, heat buildings, the density of heat flow, temperature, heat transfer, thermo building.

1. Basok B.I., Davydenko B.V., Goncharuk S.M., Kuzhel L.M. Experimental studies of heat through modern window design in actual use [electronic resource] Access: http://wt.com.ua/wt_60_2015_online/flippingbook.swf (Ukr)

2. Basok B.I., Davydenko B.V., Novytskaya M.P., Goncharuk S.M., Nedbaylo A.N. Effect of Gas-fired tolschynы stratum termycheskoe Resistance to singlechamber Thermopanes. Prom. teplotehnyka, 2012, T.34, №1, P. 100 - 107. (Rus)

3. Petrov E.V., Kachaeva S.G., Alekseev A.A. Research of influence of various factors on the thermal characteristics of translucent enclosures // Scientific Bulletin number 1 (1) 2014, Article 99 - 105. (Rus)

4. Modern Ukrainian building materials, products and konsttruktsiyi. Scientific-practical guide / K: Association конструкції в реальних умовах експлуатації // Енергоефективність у будівництві та архітектурі, 2015, №7, С. $65-71$.

7. ДСТУ Б B.2.6-17-2000 (ГОСТ 26602.1 99) Блоки віконні та дверні. Методи визначення опору теплопередачі. / Мінрегіон України. - К.: Укрархбудінформ, 2006. - $25 \mathrm{c}$.

8. МВB № 081/24-0778-11 Метрологія. Опір теплопередаванню крізь огороджувальні конструкції будівель i споруд різного призначення. Методика виконання вимірювань комбінованим тепловізійно-пірометричним методом. ІТТФ НАНУ. - 2011.

9. Конструкиії будинків та споруд. Теплова ізоляція будівель: ДБН В.2.6-31:2006. зі Зміною №1 від 1 липня 2013 року. - [Чинний від 01.04.2007]. - К.: Мінбуд України, 2006. - 70 с. - (Державні будівельні норми України).
"Ukrainian Union of Manufacturers of building materials and products," 2012. (Ukr)

5. Posilsky O. Modern types of energy-saving glass. [Electron resource] / O. Posilsky / access mode: http://www. ivit.ua/article/sovremennye_vidy_energosberegayushih_ stekol (Rus)

6. Davydenko B.V., Goncharuk S.M., Novitska M.P., Kuzhel L.M., Krasota D.O. Eksperimentalni doslidzhennya heat transfer through suchasni vikonni konstruktsiï in real minds ekspluatatsiii. Energoefektivnist in budivnitstvi that arhitekturi 2015, №7, Art. 65 - 71. (Ukr)

7. DSTU B V.2.6-17-2000 (GOST 26602.1 - 99) that blocks vikonni dverni. Metodi viznachennya support teploperedachi. / Minregion Ukraine. K . Ukrarhbudinform, 2006. 25 p. . (Ukr)

8. MBB number 081 / 24-0778-11 metrology. Opir teploperedavannyu kriz ogorodzhuvalni konstruktsiï budivel i sporud riznogo priznachennya. Methods vikonannya vimiryuvan kombinovanim teploviziyno-pirometrichnim method. ITTF NASU. 2011. (Ukr)

9. Construction of buildings and structures. Insulation of buildings: DBN V.2.6-31: 2006. With the change №1 from 1 July 2013. [Effective as of 01.04.2007]. K.:Ukraine Ministry of Construction, 2006. 70 p. (State building codes Ukraine). (Ukr)

Получено 07.02.2017 Received 07.02.2017 